\title{
Optimal Cost of a Solar Photovoltaic System for a Remote House in Bihar
}

\author{
Sujit Kumar Jha \\ Engineering Department, Ibra College of Technology, Ibra, Sultanate of Oman
}

\begin{abstract}
Energy plays a vital role for the growth of a country. Solar energy is the most important renewable energy resources that can play vital role in the replacement of fossil resources to generate clean energy. Due to technological developments in solar power technologies, solar energy can be used for cooling, heating, and daily electricity demand of the world and emerged as viable alternative to produce clean energy in future. The paper describes the technological development of PV model, its present status and future opportunities in the context of Bihar, India. The study was carried out in Bihar, global solar radiation data is required for the calculation and assessment of the working principles of PV system installed at remotely located house to provide adequate power backup. The case study has been based on the solar radiation data available in Bihar, India, the cost of a suitable PV model for a house has been computed based on the analysis of power requirement of a houses in a day.
\end{abstract}

Keywords: Solar Radiation, Solar Irradiance, Photovoltaic (PV) system, Solar Energy.

Article History: Received April 10, 2015 ; Received in revised form May 28, 2015; Accepted May 29, 2015; Available online

How to Cite This Article: Jha, S.K. (2015) Optimal Cost of a Solar Photovoltaic System for a Remote House in Bihar. Journal of Renewable Energy Development, 4(2), 153-161.

http://dx.doi.org/10.14710/ijred.4.2.153-161

\section{Introduction}

India is located in the sunny belt of the ground getting plentiful heat energy directly from the sun. Due to the geographical position of Indian and high clear sunny days in India, the average daily solar radiation is around 4.9-7.0 $\mathrm{kWh} / \mathrm{m}^{2}$ in northern-eastern area. Bihar is a state in northern India having area around 38202 $\mathrm{m}^{2}$ and near 173 feet above from sea level. The state is located between 240-20'-10" 270-31'-15" N latitude and between 830-19'-50" $\sim 88^{0}-17^{\prime}-40^{\prime \prime}$ E longitude. Bihar is surrounded by Nepal to the North and Jharkhand to the south. To the east of Bihar is West Bengal and Uttar Pradesh to its west. The temperature in Bihar is subtropical, with hot summers range from $35-42{ }^{\circ} \mathrm{C}$ and cool winters range from $0-10{ }^{\circ} \mathrm{C}$. Summer starts from April and lasts up to the middle of June. Dust storms usually occur in May with 48-64 km/hr. Monsoon starts by mid-June and lasts till end of September. Temperature drops but humidity increases. Due to huge shortage of power, a survey has been conducted by the state governments which disclosed that there is a great potential to generate the solar energy in the state. The solar radiation is estimated by sunshine duration, according to World Institute of Sustainable Energy (WISE), Bihar has around 280 sunshine days, has enough capacity to generate solar energy.

The economic and social development of the nation's energy plays important role. The availability of fossil source to generate energy and its influence on the environment versus various renewable resources and use of green power energy has been demonstrated by (Foster and Ghassemi 2010). The energy requirement is essential for social development as well as for economic development of a nation. The energy demand may be double or triple by 2050 as worldwide residents increasing and developing nations increase their economies fast. From last 200 years foremost nations relies on fossil fuels for operating power plants, trains, and automobiles, this will increase the carbon credits and emissions of greenhouse gas. There are a big question on availability of fossil fuels resources and timing for gaze advance to end of the fossil fuel era. The studies of impacts on environment by fossil fuels versus different renewable resources have been discussed by (Foster and Ghassemi 2010). A lot of research and development have applied in renewable energy

\footnotetext{
*Corresponding author: skj828@gmail.com
} 
resources as it is environmental friendly and economical as well as political issues of the world has been clarified by (Sayigh 2001). Solar energy is one of the most significant renewable energy resources considered as an alternative source of energy, there are two technologies applied to solar energy for the generation of power namely solar thermal and solar photovoltaic (IEA 2009). Prabhakant and Tiwari (2009) have examined a solar PV system to determine the carbon credits received by it, the result supports the application of solar energy compare to conventional power generation in terms of cost and environmental impacts. The efficiencies of solar photovoltaic plants connected to the grid can be increased by combined effect of soft-computing methods for enhanced solar cell models and control methods has been demonstrated by (Varnham et al. 2007). The solar radiation intensities in different regions of India have been shown in Figure 1. From the map, it has been observed that in Rajasthan, northern Gujarat and some parts of Ladakh region receive the highest annual global radiation even though some parts of Bihar receive higher global radiation compared to the other parts of the world where maximum development and endowment of solar technology is already implemented.

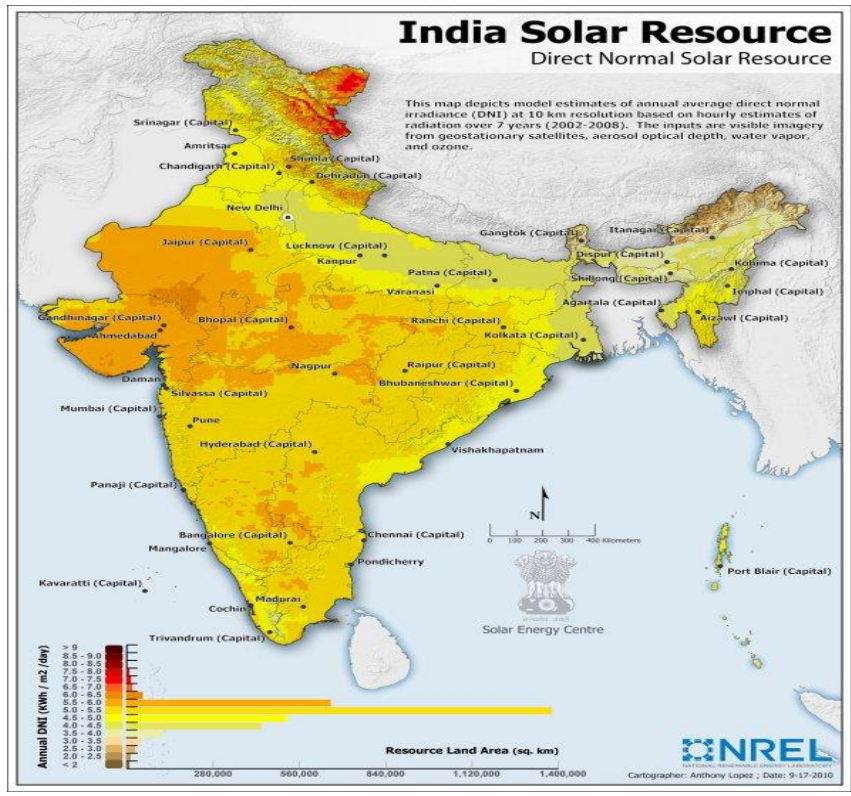

Fig. 1 Solar radiation on India (sources NREL)

Solar photovoltaic (PV) energy is one of the most universal forms of renewable energy to produce direct current (DC) measured in watts (W) or kilowatts $(\mathrm{kW})$ from semiconductor materials when sunlight focus on it during daytime. Solar energy generated, as the sunlight focus on the solar cell in the same way the generation of electricity stops as sunlight stops. The application of PV system is more in remote areas, which are far from the local grid and the people can get electricity. PV system can be used as an alternative of diesel engines for remotely placed villages. PV system also used to provide electricity to remotely placed transmitter stations. The primary source of energy is combustion of fossil fuel (coal, petroleum and natural gas) or nuclear fission to generate electricity whereas the secondary source of energy is generated by PV system. In PV system, solar cells are combined and enclosed into unit called PV module that can contains around 40 cells, similarly around 10 modules are combined and mounted in PV arrays to generate DC current that can be transformed into AC current by using inverter. About 8 to $26 \mathrm{PV}$ arrays are used to provide electric power for a household and more than hundreds of arrays can be used to generate power for industrial applications. Generally, two types of inverters are used in a PV system, one as modified sine wave and other as pure sine wave. The operating cost of a modified sine wave inverter is cheap but less efficient than pure sine wave, which work without the buzz sound with most efficient way. For non-grid connected solar PV system for a house need battery to store energy for night functioning of light and fans. Generally, tubular lead-acid is the most suitable for a PV system, which can supply power for longer durations and also can be used up to $80 \%$ of its capacity repeatedly. Presently, the utilizations of solar energy in Bihar is restricted to very few applications like remotely located telecommunication station, street lighting in cities, Solar Home Lights, Solar Lanterns etc has been explained by (Sujit 2013). The evaluation and practicability of power generation using PV cells in Qatar has been investigated by compared with conventional gas turbine and concluded that PV systems are not viable due to high investment, but due to application of emerging technologies to a PV system for generating power with lower cost, which can be implemented to remote areas have been demonstrated by (Marafi and Ashour 2001). Gera et al. (2013) reviewed the renewable energy scenario in India and demonstrated an overview of renewable energy whereas evaluating the current status of energy demand and forecast of its consumption, with the objective to assess the growth of India with renewable resources. Majid et al. (2013) have explained the design and analysis of Photovoltaic (PV) system to generate and provide power supply to Renewable Energy Laboratory. Ahmad and Byrd (2013) did analysis on solar PV system installed on roof of remotely located house in Malaysia after calculating energy consumption of all households. The paper demonstrated the significant potential of PV system in rural areas in Malaysia.

The main focus of this study is to identify the importance of the solar energy and its propriety in consideration of Bihar. For the economic and society development of the state, this research focuses on the development and implementation of solar power technologies like PV system as another source of energy. The paper has studied the PV technologies for the generation of energy and its utilization as well as 
optimizes the cost of PV system for a typical house remotely located in Bihar. A specific knowledge has been developed and used for the installation of specific energy converters and then energy sources have accepted for the implementation of renewable and nonrenewable energy and a decrease of $\mathrm{CO}_{2}$ emissions have presented by (Fabrizio et al. 2010).

The purpose of this study is to calculate approximately the cost of a proposed PV system and its solar panel dimension used for a house remotely situated village in Bihar. The paper is prepared as follows: section 2 illustrates the background of Photovoltaic System to produce the electricity for a remotely situated house. After this, paper described the present and future power scenario in Bihar under section 3. In section 4, the paper suggested and estimated the sizing of solar system and its design based on the current technologies available in the market and finally, the paper presented the results and conclusions in section 5 .

\section{Background of Photovoltaic System}

The primary source of renewal energy is solar energy or photovoltaic (PV) system with or without conventional power back-up, which can be applied to the applications consuming low or high power in remote areas. The semi conducting materials are used in solar cells in PV system to absorb the heat energy from daylight and given to the electrons for random free movement of electrons to generate electricity. The developed solar cells are interconnected and joined into modules which further installed in PV arrays of several meters in length. For efficient utilization of PV system, Flat-plate arrays installed at a fixed angle in the direction of sunlight, or can be installed with a tracking device for maximum capturing of sunlight over the day. According to the household requirements, the number of PV arrays can be computed and mounted for a typical house, for example there are 8-30 PV arrays are sufficient to supply power to a house hold applications. For industrial application or large electricity demands, hundreds of arrays can be interconnected to form a single PV system.

The performance of solar cells can be increased by using a lens to concentrating collectors to focus the sunlight onto the cells that can be estimated by its efficiency during converting the heat energy from the sunlight into electricity. A typical solar cell has an efficiency of $15 \%$, lower cell efficiency means more number of arrays required to generate desired power but this will increase the cost of solar cell. Still a lot of research going on for improving solar cells materials to improve the efficiency of solar cell by reducing the cost per cell. During 1950s, first solar cells manufactured had efficiency less than $4 \%$. The demand of PV system can be increased by developing low cost new materials, which further causes the cost of PV system coming down and finally its demand internationally will be enhances (Sujit 2013). The nano materials have been applied in low to high-temperature collectors, photovoltaic materials and thin films for direct conversion of electricity. Khan et al. did research on advanced materials and developed a high performance thin film PV cells for the production of electricity at competitive cost to fossil-derived electricity presented by (Khan et al. 2008). Figure 2 shows the PV array system for a typical house.

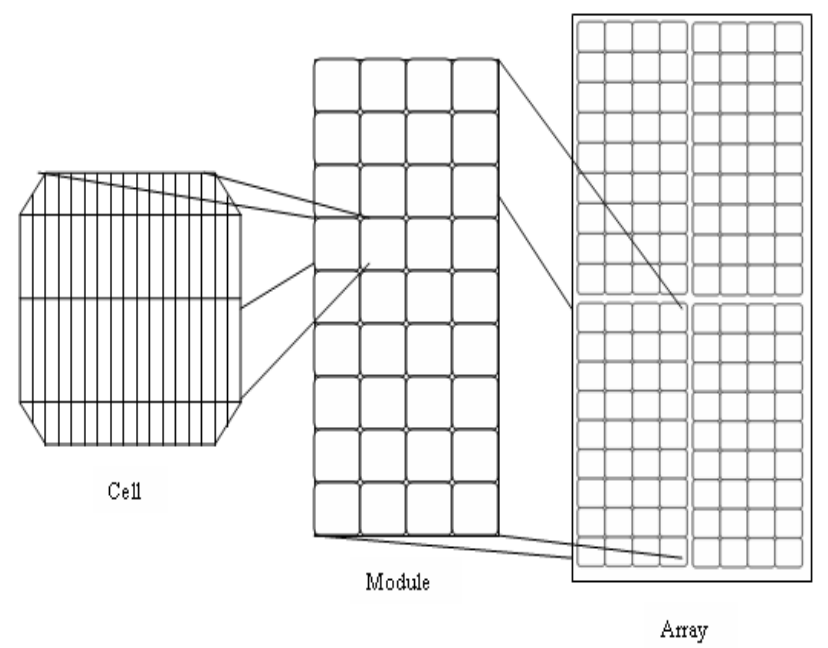

Fig. 2 Solar PV cells, modules and Arrays

The price of a PV system mainly depends on the number of arrays used and its capacity and also it varies from countries to countries. Generally, the cost of PV system differs from residential application (2 kW) of $\$ 4.5 / \mathrm{W}$ to commercial application of capacity (750 kW) of $\$ 5.5 / \mathrm{W}$. The capacity and output of a PV system depends on the orientation of installed flat plate, total irradiance at site, spectral irradiance, air temperature, wind speed and different losses associated to system. The panels of a PV array is weathered proof panels can be used as roof-mounting and appropriate for all climates easily fixed on tile or flat roofs. The efficiency of a PV system can be measured as:

$$
\eta=\frac{P_{\max }}{E_{\text {tot }} \cdot A} \times 100
$$

where $\mathrm{P}_{\max }$ is peak PV power, $\mathrm{A}$ is device area and $\mathrm{E}_{\text {tot }}$ is total incidence irradiance.

The solar declination angle, $\delta$ is the angle between the equatorial plane and a straight line between centre of sun and earth is constantly changing throughout the year. The performance of a PV system mounted at a place on the Earth's surface depends on the position of the sun by two angles that refer to the horizontal and vertical, respectively. The solar constant is the power incident on a unit area at right angles to beam focus on the atmosphere of earth reaches to $1 \mathrm{AU}$, which can be represented as: $B_{0}=1367 \mathrm{~W} / \mathrm{m}^{2}$. The entire solar radiation falling on the Earth's surface is the addition of beam radiation, diffuse radiation, and albedo radiation 
Citation: Jha, S.K. (2015) Optimal Cost of a Solar Photovoltaic System for a Remote House in Bihar. Journal of Renewable Energy Development, 4(2), 153-161, doi.org/10.14710/ijred.4.2.153-161

P a g e 156

called global radiation has been detail explained by (Lorenzo 2011). Solar irradiance is the density of power coming on the Earth's surface, measured in $\mathrm{W} / \mathrm{m}^{2}$, whereas solar irradiation is the density of the energy that falls on the surface over some period of time, for example, hourly irradiation or daily irradiation, and is measured in $\mathrm{W} \mathrm{h} / \mathrm{m}^{2}$.

Iqbal (1983) has described the technique to determine the variation in the quantity of global radiation collected at the receiver theoretically by geometrical consideration. For instance, the outer space irradiance over a horizontal plane is given by $B_{0}(0)=B_{0} \varepsilon_{0} \cos \theta_{S Z}$ which when incorporated over the day provide the average daily energy on a horizontal plane for a particular month can be given as:

$$
B_{0 d}(0)=\frac{T}{\pi} B_{0} \varepsilon_{0}\left[-\frac{\pi}{180} \omega_{S} \cdot \sin \delta \cdot \sin \phi-\cos \delta \cos \phi \sin \omega_{S}\right]
$$

where $\theta_{S Z}$ is solar zenith angle and $\mathrm{T}$ is the day duration 24 hours, solar declination angle is $\delta$, geographic latitude is represented by $\phi$ and the sunrise angle $\omega_{\mathrm{s}}$ can be known as: $\omega_{S}=\cos ^{-1}(-\tan \phi \tan \delta)$

\section{Working principle of PV system}

Photovoltaic cells directly convert heat energy from sun into electricity with no pollution to the environment. PV cells are made of layer by layer of semiconductor material, one end layer works as a positive charge and other end layer as a negative charge. When daylight falls on the cells, a number of the photons from the light source are absorbed by the atoms of semiconductor materials causes to release the electrons from the negative layer of PV cells to run through an outer circuit and finally return to the positive layer of cells by this way generates current. To increase the output of PV cells and its efficiency, numbers of entity PV cells are joined together in a weatherproof and sealed manner to manufacture a module. The correlation of two modules for receiving preferred output has been shown in Figure 3.
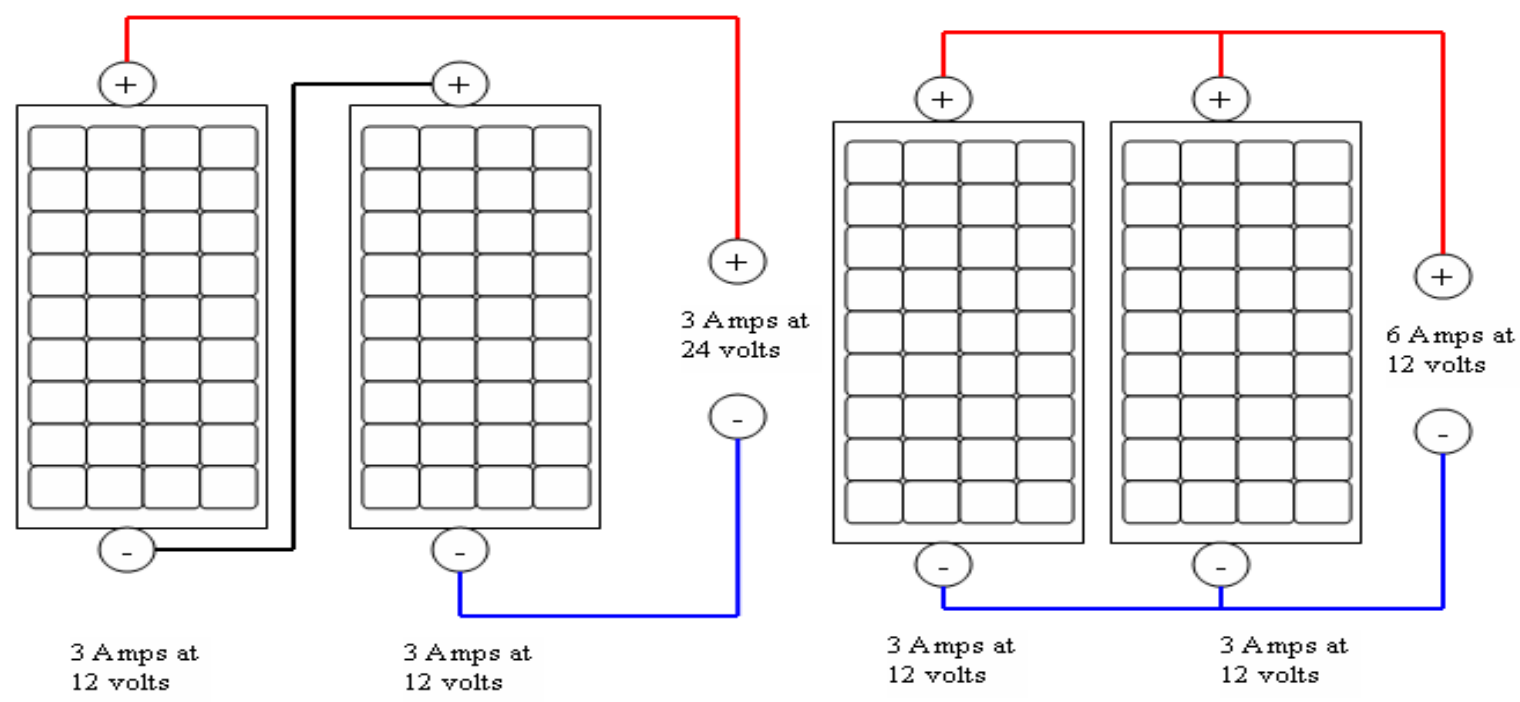

Fig. 3 The connection of PV System in series (left side) and in parallel (right side)

By joining two modules in series as shown in Figure 3 , the output of current for the resultant system is constant while voltage becomes double. In the same way, by joining two modules in parallel, the output of voltage for the resultant system is constant whereas current becomes double. To get the desired current and voltage, modules are connected in series and parallel named as PV array. The output of PV panel array can be determined by multiplying the total output current and voltage. There are enormous amount of solar energy available in Bihar, but due to lack of government policies and higher initial cost of PV panel not promoted more, therefore many remotely located villages still using diesel/kerosene to generate electric power and for water pumping system that can be substituted by applying PV system, which is environmental friendly.

\section{Power Scenario in Bihar}

When Jharkhand separated from Bihar in 2000, the generation of electricity became critical because most of running power plant fell into newly formed state Jharkhand. Bihar is mainly dependent on National Thermal Power Corporation (NTPC) and other states electricity board for supply power. In 2000 Bihar has only 590 MW electricity generation capacities but demand was $1500 \mathrm{MW}$ that has taken from NTPC and Jharkhand Electricity board. According to $3^{\text {rd }}$ North East 
\& East Power Summit, 2010 only $52.8 \%$ of villages and $6 \%$ of households are electrified. According to the CEA, in 2009 the annual per capita consumption in Bihar is currently at 95 units, against a national average of 717 units. Around $85 \%$ of populations residing in rural areas mainly rely on kerosene and diesel for lighting or power generation. According to a report prepared by 17th Electric Power Survey Committee incorporated energy requirement in Bihar is 3607 MW for 2011-2012 year and the same is 5598 MW for the year 2016-2017 (Bihar Electricity Regulation Board, 2010).

There are significant potential of renewable energy in Bihar, which has less impact on the environment and can be used to reduce the scarcity of power in the state in the form of solar energy, wind energy, hydro power, biomass, etc for lighting in the villages, water pumping system for irrigation and captive power plant for industries production. The government has formed a separate entity as Bihar Renewable Energy Development Agency (BREDA) for the development and execution of renewable energy in the state. There has been significant improvement in power scenario by year 2012 with the availability rising to $2300 \mathrm{MW}$ during the festive season and the same will increase to 2600 MW by August 2014, according to the sources from energy department (Bihar Electricity Regulation Board, 2010).

\subsection{Insolation Data in Bihar}

The solar insolation defined as the solar radiation falls on a particular place during a given period of time, typically a single day. In broader sense, insolation is solar radiation received at any place on the Earth's surface, which value can be dependent on the altitude of that place, atmosphere condition of it and the sun's angle. The solar radiation data at location in Bihar has been computed based on monthly average daily global solar radiation by means of measurement of global solar radiation. In this research, te $\mathrm{n}$ different districts location coordinates with their climate data and global solar radiation data based on annual rate has been shown in Table 1 . The global solar radiation data has been taken from a report mentioning the monthly climate data issued by the renewable energy department of Bihar government for each district (MNRE 2008; Debajit 2003).

The global solar radiation data varies from year to year as well as varies from location to location. The global solar radiation data for ten districts in Bihar at different locations have been presented in the Table 2. The global solar radiation is the summation of diffuse and beam radiation, the quantity of it coming on the Earth's surface at any location depends on following factors:

- The solar elevation

- The duration of day

- The turbidity of air

- The amount and type of clouds

Among all above factors, the first two are most important factors that can be even calculated. The average solar insolation data measured at any place on a horizontal surface given in $\mathrm{kWh} / \mathrm{m}^{2} /$ day and for ten different cities in Bihar this value given as: at Gaya 4.94 $\mathrm{kWh} / \mathrm{m}^{2}$, Madhubani $4.96 \mathrm{kWh} / \mathrm{m}^{2}$, Darbhanga 5.28 $\mathrm{kWh} / \mathrm{m}^{2}$, Patna $5.22 \mathrm{kWh} / \mathrm{m}^{2}$, Samastipur 5.22 $\mathrm{kWh} / \mathrm{m}^{2}$, Siwan $5.28 \mathrm{kWh} / \mathrm{m}^{2}$, Muzaffarpur 5.28 $\mathrm{kWh} / \mathrm{m}^{2}$, Bhagalpur $5.15 \mathrm{kWh} / \mathrm{m}^{2}$, Bettiah 4.88 $\mathrm{kWh} / \mathrm{m}^{2}$, and Chhapra $5.15 \mathrm{kWh} / \mathrm{m}^{2}$ per day. Table 1 represents the geographical locations of ten districts in Bihar with average temperature, humidity and pressure. Table 2 represents.

Table 1.

Locations of 10 districts and Global Solar radiation from NASA and MNRE

\begin{tabular}{ccccccccc}
\hline Locations & $\begin{array}{c}\text { Latitude } \\
\left({ }^{\circ} \mathrm{N}\right)\end{array}$ & $\begin{array}{c}\text { Longitude } \\
\left({ }^{0} \mathrm{E}\right)\end{array}$ & $\begin{array}{c}\text { Altitude } \\
(\mathrm{m})\end{array}$ & $\begin{array}{c}\text { Air } \\
\text { Temperature } \\
\left({ }^{\circ} \mathrm{C}\right)\end{array}$ & $\begin{array}{c}\text { Relative } \\
\text { Humidity } \\
(\%)\end{array}$ & $\begin{array}{c}\text { Air } \\
\text { Pressure } \\
(\mathrm{kPa})\end{array}$ & $\begin{array}{c}\text { Global Solar } \\
\text { Radiation from } \\
\text { NASA } \\
\left(\mathrm{kWh} / \mathrm{m}^{2} / \mathrm{day}\right)\end{array}$ & $\begin{array}{c}\text { Global Solar } \\
\text { Radiation from } \\
\text { MNRE } \\
\left(\mathrm{kWh} / \mathrm{m}^{2} / \mathrm{day}\right)\end{array}$ \\
\hline Gaya & 24.78 & 85.00 & 110 & 24.6 & 61.6 & 98.1 & 4.89 & 5.41 \\
Madhubani & 26.37 & 86.08 & 55 & 21.2 & 63.7 & 92.7 & 5.24 & 5.14 \\
Darbhanga & 26.17 & 85.90 & 38 & 22.5 & 61.7 & 95.1 & 5.27 & 5.13 \\
Patna & 25.60 & 85.12 & 49 & 24.7 & 61.2 & 98.8 & 5.21 & 5.21 \\
Samastipur & 25.85 & 85.78 & 38 & 24.7 & 61.2 & 98.8 & 5.21 & 5.15 \\
Siwan & 26.22 & 84.37 & 63 & 23.6 & 59.9 & 97 & 5.27 & 5.10 \\
Muzaffarpur & 26.12 & 85.40 & 46 & 22.5 & 61.7 & 95.1 & 5.27 & 5.13 \\
Bhagalpur & 25.25 & 87.02 & 40 & 24.1 & 65.7 & 98.5 & 5.09 & 5.19 \\
Chapra & 25.77 & 84.75 & 47 & 23.6 & 59.9 & 97 & 5.14 & 5.19 \\
Bettiah & 26.80 & 84.50 & 64 & 23.6 & 59.9 & 97 & 5.27 & 4.07 \\
\hline
\end{tabular}


Citation: Jha, S.K. (2015) Optimal Cost of a Solar Photovoltaic System for a Remote House in Bihar. Journal of Renewable Energy Development, 4(2), 153-161, doi.org/10.14710/ijred.4.2.153-161

$\mathrm{P}$ a g e 158

Table 2.

Global Solar radiation data for ten different cities in Bihar $\left(\mathrm{kWh} / \mathrm{m}^{2} / \mathrm{day}\right)$.

\begin{tabular}{|c|c|c|c|c|c|c|c|c|c|c|}
\hline $\begin{array}{l}\text { Months / } \\
\text { Locations }\end{array}$ & Gaya & Madhubani & Darbhanga & Patna & Samastipur & Siwan & Muzaffarpur & Bhagalpur & Bettiah & Chhapra \\
\hline Jan & 4.12 & 4.35 & 4.06 & 4.18 & 4.18 & 4.03 & 4.06 & 4.20 & 4.21 & 4.07 \\
\hline Feb & 5.06 & 4.80 & 5.25 & 5.28 & 5.25 & 5.21 & 5.25 & 5.29 & 4.73 & 5.21 \\
\hline Mar & 5.84 & 5.51 & 6.39 & 6.29 & 6.26 & 6.40 & 6.39 & 6.27 & 5.29 & 6.19 \\
\hline Apr & 6.36 & 6.26 & 6.98 & 6.96 & 6.95 & 7.03 & 6.98 & 6.85 & 6.17 & 7.00 \\
\hline May & 6.45 & 6.53 & 7.07 & 6.93 & 6.90 & 7.15 & 7.07 & 6.74 & 6.60 & 6.54 \\
\hline Jun & 5.29 & 5.42 & 5.88 & 5.75 & 5.74 & 5.98 & 5.88 & 5.58 & 5.22 & 5.91 \\
\hline Jul & 4.38 & 4.76 & 4.63 & 4.57 & 4.57 & 4.62 & 4.63 & 4.49 & 4.43 & 4.50 \\
\hline Aug & 4.33 & 4.53 & 4.73 & 4.65 & 4.61 & 4.66 & 4.73 & 4.51 & 4.49 & 4.57 \\
\hline Sep & 4.33 & 4.60 & 4.52 & 4.47 & 4.43 & 4.48 & 4.52 & 4.24 & 4.46 & 4.53 \\
\hline Oct & 4.08 & 4.72 & 5.07 & 4.98 & 4.96 & 5.09 & 5.07 & 4.90 & 4.74 & 4.81 \\
\hline Nov & 4.38 & 4.48 & 4.75 & 4.75 & 4.72 & 4.72 & 4.75 & 4.71 & 4.40 & 4.52 \\
\hline Dec & 4.00 & 3.58 & 4.02 & 4.1 & 4.07 & 4.00 & 4.02 & 4.07 & 3.76 & 3.91 \\
\hline Average & 4.94 & 4.96 & 5.28 & 5.24 & 5.22 & 5.28 & 5.28 & 5.15 & 4.88 & 5.15 \\
\hline
\end{tabular}

\subsection{The evaluation of the data}

The average global solar insolation data in Bihar varies from $4.88-5.28 \mathrm{kWh} / \mathrm{m}^{2} /$ day, equivalent to 1781.4 - 1927.4 kWh per year. The variation between the highest and the lowest daily mean insolation is significant when the variation is low. For a location like Madhubani the variation in global insolation data for January month is from 2.1 to $4.8 \mathrm{kWh} / \mathrm{m}^{2}$ per day where as for the month March to June the variation is from 4.5 to $6.8 \mathrm{kWh} / \mathrm{m}^{2}$ per day. The annual global solar insolation variation in January is $4.35 \mathrm{kWh} / \mathrm{m}^{2}$ per day and the same for May is about $6.53 \mathrm{kWh} / \mathrm{m}^{2}$ per day that is highest value for a year (Bihar Electricity Regulation Board, 2010). Solar insolation data in Table 2 shows that Bettiah, Gaya and Madhubani have a considerably lower value than other districts in the state. The main reason is due to the fog and rainy season from July to September.

\subsection{Current status of the off-grid solar projects}

Table 3 represents the solar projects installed in the state Bihar.

Table 2.

Installed solar system in the state (according to BREDA data)

\begin{tabular}{lll}
\hline & System & Nos. \\
\hline 1 & Solar Wind mills & 269 \\
2 & Solar Cooker & 500 \\
3 & Solar Street Lights & 684 \\
4 & Solar Home Lights & 5471 \\
5 & Solar Lantern & 42975 \\
6 & Solar Hot Water & $127800 \mathrm{lpd}$ \\
\hline
\end{tabular}

\subsection{Current status of grid connected solar power projects}

Till now no solar power projects are registered under solar mission phase 1. Bihar government has approved 9 solar power projects of total capacity $366 \mathrm{MW}$, involving investments of 5562.72 crores at Muzaffarpur, Madhubani, Gaya, Bhagalpur, Aurangabad, Patna, Purnea, Champaran, Saran, Bettiah, Bhojpur and Samastipur districts. Bihar Renewable Energy Development Agency (BREDA) Director has announced new energy policy to attract capital investments, as the energy department confirmed that some of the companies already made agreement to setup plants at various districts and some of them started their leg work to setup power plants. Some of them are following:

- Response Renewable, Kolkata agree to setup 25 MW capacity plant in Buxar, Madhubani and Chhapra.

- Moserbaer Clean Energy, Delhi agreed to setup total 85 MW at Chakiya, Ramnagar, Katoriya and Banka.

- Clairo Energy, Delhi agreed to setup $10 \mathrm{MW}$ at Gopalganj and Khagaria.

- Chaintey Partners of New York have decided to setup $10 \mathrm{MW}$ at Kaimur.

- Chaucer Capital of London agreed to setup 20 MW at Gaya and Dobhi.

The government of India is promoting PV solar system through Ministry of New and Renewable Energy (MNRE) under Jawaharlal Nehru National Solar mission scheme in the country. The level of subsidy by MNRE is around $30 \%$ on total funds disbursements for rooftop solar system for residential as well as commercial 
purpose, which decreases the cost of capital expenditure by investors which also provided by the government in terms of loan at 5\% per annum for 50-60 $\%$ of the total cost for 5 years tenure. Generally, $1 \mathrm{~kW}$ capacity solar system will generate around $1600-1700$ $\mathrm{kWh}$ of electricity per year and required 10 sq. m area to installed it. The cost of a typical rooftop solar system without grid connection varies from Rs. 45 - Rs. 125 per watt depends on the quality of the module and locally manufactured or imported (MNRE 2008; Debajit 2003).

\section{Solar System Sizing Estimation}

The paper has considered a case study for a typical house remotely located in Madhubani, Bihar using solar energy for power generation. The PV systems used for a typical house depends mainly on the necessities and the states under which energy required. This paper has considered non-grid connected solar PV system, which use special inverter and battery to store power generate by PS system installed. This will adds major cost and design complexity to a PV system. Due to shortage in power availability through grid, the cost of solar PV system will increase for the requirements of battery for power backup during night for lighting, fans and TV.

\subsection{Case Study for a remotely located house}

PV module can be easily installed on the roof of the house to directly convert DC electricity from 5-15\% of the solar energy. The generated DC electricity can be stored in a battery and used just like the electricity produced by batteries, which further can be converted into AC electricity by using a converter to use in conventional electrical device. PV module consists of a number of arrays to produce specific quantity of energy. In this research, paper has computed the requirement of number of panels for a specific power requirement of a typical house. The daily requirement of electricity for a house remotely placed at Kasera, the small village of Madhubani district, Bihar, India mostly populated by Brahmans, kyots and muslims. Madhubani is situated in north-eastern region of the state, having geographical area of $3501 \mathrm{sq}$. $\mathrm{km}$. The district is located between $26.37\left({ }^{\circ} \mathrm{N}\right)$ latitude and $86.08\left({ }^{\circ} \mathrm{E}\right)$ longitudes at height of $58 \mathrm{~m}$ from sea level. Madhubani is bounded by hill region of Nepal in north, Darbhanga in south, Supaul in east and sitamarhi in west. The village has around 160 households under Umgaon block, situated at $22 \mathrm{~km}$ away from Madhubani, and has very poor electricity grid connection and also electricity availability. The computation of exact load requirement at a proper time of a typical house is difficult as load requirement varying from time to time. But for proper design of a PV system, the exact load requirement is important to reduce the capital and operational costs of the system. The village comprises of houses having average of 4-8 people live in each house based on the information collected. Based on the survey conducted in a remotely located village, the power requirement of a house in summer will vary from $750 \mathrm{~W} / \mathrm{h}$ to $3876 \mathrm{~W} / \mathrm{h}$ during a day. The instalment of PV system need high initial investment so it is best for saving energy with electrical devices used in the household should be utilized more rather than spending on large unit. The maximum requirement of power in a house is the sum of the rating of the electrical appliances used over a specified time interval. The total load consumed by a specific electrical device can be computed by multiplying the total hours used of that appliance by the ratings of the appliances and by number of appliances used at same time interval has been shown in Table 2. A research on change of load by an individual user or group of users connected to distribution system changing continuously as well as maximum non-coincident demand variation over a specified time. The non-coincident demand for a group of loads is the sum of all individual demands without any restriction during the same time interval has been presented in (Gelling 1995). The power demand of individual customers can be determined either from meter installed or from knowledge of the energy consumed by customer. Arvidson in 1940 developed a technique of computation of distribution loads in residential areas by the diversified demand method using diversity factors presented in (Gonen 2008).

The anticipation of daily load requirement for simple loads like electrical lights, fans, freeze, water pump or other electrical appliances is easy and accordingly suitable design of a PV system can be made. On the other hand, it is very difficult to determine the exact load requirement for complex loads used in a house like daily used hours of AC, Freeze, TV, Lights, Fans, Coffee pot, etc. Due to this calculated watts hour should be multiplied by 1.2 as "fudge factor". From Table 2 for a typical house, total power requirement has been calculated as $20205 \mathrm{~W}$ $\mathrm{h} /$ day $=20.205 \mathrm{kWh} /$ day, which further multiplied by 1.2 gives the total power need for considered house is $24.25 \mathrm{kWh} /$ day.

The quantity of valuable sunshine offered to the PV panels on an average day throughout the worst month of the year is called the "insolation value". The most of districts in Bihar have the average solar insolation values varies from 3.1 to $5.0 \mathrm{kWh} / \mathrm{m}^{2} /$ day for the month of December, which is considered as reference for optimal design of a PV panel for smooth working of it. The interpretation of insolation value is the $\mathrm{kW}$ $\mathrm{h}$ /day of sunlight energy collected by one square meter of solar panels at latitude tilt. The array size can be determined dividing the daily energy requirement by the daily sun hours. For power requirement of 24.25 $\mathrm{kWh}$ /day and in Madhubani district minimum value of insolation data is $3.58 \mathrm{kWh} / \mathrm{m} 2 /$ day and its average value for a year is $4.96 \mathrm{kWh} / \mathrm{m} 2 /$ day, hence $24.25 / 4.96$ $=4.89 \mathrm{~kW}$ capacity plant should be installed. The need of energy in a typical house has been shown in Table 4 for all installed appliances. 
Citation: Jha, S.K. (2015) Optimal Cost of a Solar Photovoltaic System for a Remote House in Bihar. Journal of Renewable Energy Development, 4(2), 153-161, doi.org/10.14710/ijred.4.2.153-161

P a g e 160

Table 4.

Appliances used in a typical house at Kasera in Biahr (summer)

\begin{tabular}{|c|c|c|c|c|c|c|}
\hline $\begin{array}{c}\text { Electrical } \\
\text { Appliances }\end{array}$ & $\begin{array}{c}\text { Number of } \\
\text { applications }\end{array}$ & $\begin{array}{l}\text { Rated Power } \\
\text { (Watt) }\end{array}$ & $\begin{array}{c}\text { Total Power } \\
\text { Consumption } \\
\text { (Watt) }\end{array}$ & Hours Used/day & hrs $\times$ rating $\times$ no. used & Watts /day \\
\hline Freezer & 01 & 600 & 600 & 12 & $12 \times 600 \times 1$ & 7200 \\
\hline Submersible Pump & 01 & 735 & 735 & 1 & $1 \times 735 \times 1$ & 735 \\
\hline Ceiling Fan & 03 & 75 & 225 & 10 & $10 \times 75 \times 3$ & 2250 \\
\hline Refrigerator & 01 & 450 & 450 & 12 & $12 \times 450 \times 1$ & 5400 \\
\hline $\mathrm{TV}$ & 01 & 110 & 110 & 10 & $10 \times 110 \times 1$ & 1100 \\
\hline Coffee Maker & 01 & 1200 & 1200 & 0.3 & $0.3 \times 1200 \times 1$ & 360 \\
\hline Computer System & 01 & 250 & 250 & 4 & $4 \times 250 \times 1$ & 1000 \\
\hline Vacuum Cleaner & 01 & 900 & 900 & 0.2 & $0.2 \times 900 \times 1$ & 180 \\
\hline Washing Machine & 01 & 1100 & 1100 & 0.5 & $0.5 \times 1100 \times 1$ & 550 \\
\hline Microwave & 01 & 1100 & 1100 & 0.5 & $0.5 \times 1100 \times 1$ & 550 \\
\hline Lights & 6 & 40 & 240 & 5 & $5 \times 40 \times 6$ & 1200 \\
\hline $\begin{array}{l}\text { Other resources like } \\
\text { mobile charger } \\
\text { video/ cassett } \\
\text { recorder }\end{array}$ & 01 & 40 & 40 & 2 & $2 \times 40 \times 1$ & 80 \\
\hline & Total & & 7250 & & & 20205 \\
\hline
\end{tabular}

This paper has considered the rating of PV panel as $185 \mathrm{~W}$ that can be used for power production, then total no. of panels required to generate same power $=$ $4889 / 185=26$. Hence, PV system required 26 panels of rating 185 watt to produce the calculated power. The installation cost of a PV panel of above rating has been considered as Rs. 75 per watt, so the total cost for the installation of 26 panels will be the cost of Rs. 3,66,675, whereas the panel dimension is around $1580 \times 808 \times$ $35 \mathrm{~mm}$. The PV system is non-grid interactive system, which requires full load capacity battery backup and one inverter which will further increase the cost of system. Total cost of a rooftop solar system is sum of PV module cost, inverter cost, copper cables cost, batteries cost, mounting structure cost, installation cost, etc. The increased cost is viable after getting support from the Bihar Government in terms of subsidy, which is $30 \%$ according to MNRE and loan. For 4-5 kW capacity solar systems need $15 \mathrm{kVA}$ capacity inverter and a battery capacity $160 \mathrm{~A}-\mathrm{h}$. The battery capacity has been computed based on the demands of electricity at night.

\section{Conclusion}

For optimal design and computation of the size of a PV system, solar radiation data play very important role. The initial cost of a PV system can be justified by the savings in the lower operation and maintenance cost during life span of the PV system, which is around 25 years and having less impact on the environment. In this paper, global solar radiation data for ten districts in Bihar has been presented in the
Table 2. The paper has considered the appropriateness and viability of PV system for a remotely located house in Bihar and the optimal size and cost of the PV array have been computed based on the requirements of a remotely located house.

\section{References}

[1] Foster, R., Ghassemi, M., Cota, A., (2010) Solar Energy, Renewable Energy and the Environmental, CRC Press Taylor \& Francis Group, Boca Raton, ISBN 978-1-4200-7566-3.

[2] Sayigh, A. A. W. (2001) Renewable energy: global progress and examples, Renewable Energy, WREN, pp. 15-17.

[3] IEA, 2009, International Energy Outlook, accessible at http://www.eia.doe.gov/oiaf/ieo/pdf/electricity.pdf.

[4] Prabhakant and Tiwari, G. N. (2009) Evaluation of carbon credits earned by energy security in India. Int. J. Low-Carbon Technol., 4, 42-51.

[5] Varnham, A., Al-Ibrahim, A. M., Virk, G. S., and Azzi, D. (2007) Soft-Computing Model-Based Controllers for Increased Photovoltaic Plant Effectiveness, IEEE Transaction on Energy Conversion, 22 (4), pp. 873-885.

[6] Sujit Kumar Jha, Application of Solar Photovoltaic System in Oman - Overview of Technology, Opportunities and Challenges, International Journal of Renewable Energy Research, Vol. 3(2), pp. 331-340, 2013.

[7] Marafi, A. H., Ashour, H. A. (2001) Feasibility study of photovoltaic technology in Qatar, Renewable Energy, 24, pp. 565567.

[8] Gera, R.K., Rai, H.M. (2013) Yunus Parvej, Himanshu Soni, Renewable Energy Scenario in India: Opportunities and Challenges, Indian Journal of Electrical and Biomedical Engineering, Vol.1(1), pp. 10-16.

[9] Majid Alabdul Salam, Ahmed Aziz, Ali H A Alwaeli, Hussein A Kazem (2013) Optimal sizing of photovoltaic systems using HOMER for Sohar, Oman, International Journal of Renewable Energy Research, Vol. 3(2), pp. 301-307.

[10] Ahmad N.A., and Byrd, H. (2013) Empowering Distributed Solar PV Energy for Malaysian Rural Housing: Towards Energy 
Security and Equitability of Rural Communities, Int. Journal of Renewable Energy Development, 2(1), 59-68.

[11] Fabrizio, E., Corrado, V., Filippi, M. (2010) A model to design and optimize multi-energy systems in buildings at the design concept stage, Renewable Energy, 35, pp 644-655.

[12] Khan, M. R., Merfeld, D. W., Pearsall, T. P., Geyer, M., Dauskardt, R. H. (2008) Innovations in Solar Power, Advanced Materials and Processes, 166 (11), pp. 45-48.

[13] Eduado Lorenzo (2011) Handbook of Photovoltaic Science and Engineering, $2^{\text {nd }}$ edition by John Wiley \& Sons, Ltd., pp. 10141072.

[14] Iqbal, M (1983) An Introduction to Solar Radiation, Academic Press, Ontario.

[15] Bihar Electricity Regulatory Commission Renewable purchase obligation, its compliance and REC framework implementation regulation, 2010.
[16] Solar radiation handbook, solar energy centre, MNRE and Indian Metrological department, 2008.

[17] Debajit Palit (2003) Renewable Energy in North East India; Issues and prospects, International Conference on Energy and Environmental Technologies for Sustainable Development, pp. 8593.

[18] Gelling, C (1995) Demand side management, EPRI, selected paper on demand side management.

[19] Gonen, T (2008) Electric Power Distribution Engineering, $2^{\text {nd }}$ edition, Taylor \& Francis Group. 